\title{
Effectiveness of Mobile Health Interventions on Diabetes and Obesity Treatment and Management: Systematic Review of Systematic Reviews
}

Youfa Wang ${ }^{1,2^{*}}$, MS, MD, PhD; Jungwon Min ${ }^{1,3 *}$, MS, PhD; Jacob Khuri ${ }^{4}$, MPH; Hong Xue ${ }^{5}$ MS, PhD; Bo Xie ${ }^{6,7}$, MS, PhD; Leonard A Kaminsky ${ }^{1}$, PhD; Lawrence J Cheskin ${ }^{8,9}$, MD

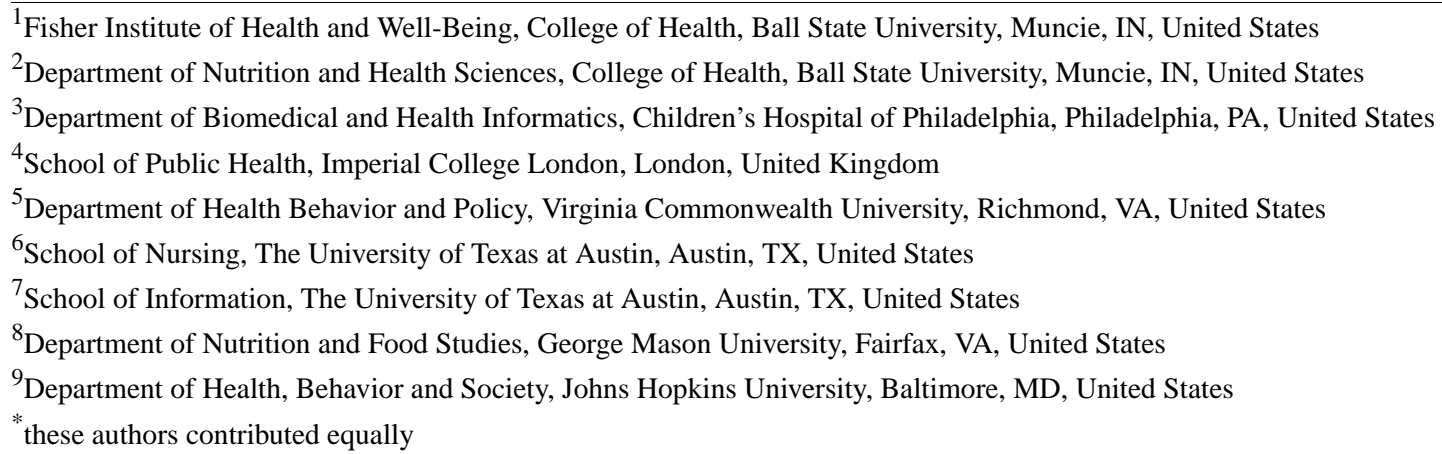

\section{Corresponding Author:}

Youfa Wang, MS, MD, PhD

Fisher Institute of Health and Well-Being

College of Health

Ball State University

2000 W University Ave

Muncie, IN, 47306

United States

Phone: 17652858259

Email: youfawang@gmail.com

\section{Abstract}

Background: Diabetes and obesity have become epidemics and costly chronic diseases. The impact of mobile health (mHealth) interventions on diabetes and obesity management is promising; however, studies showed varied results in the efficacy of mHealth interventions.

Objective: This review aimed to evaluate the effectiveness of mHealth interventions for diabetes and obesity treatment and management on the basis of evidence reported in reviews and meta-analyses and to provide recommendations for future interventions and research.

Methods: We systematically searched the PubMed, IEEE Xplore Digital Library, and Cochrane databases for systematic reviews published between January 1, 2005, and October 1, 2019. We analyzed 17 reviews, which assessed 55,604 original intervention studies, that met the inclusion criteria. Of those, 6 reviews were included in our meta-analysis.

Results: The reviews primarily focused on the use of mobile apps and text messaging and the self-monitoring and management function of mHealth programs in patients with diabetes and obesity. All reviews examined changes in biomarkers, and some reviews assessed treatment adherence $(n=7)$ and health behaviors $(n=9)$. Although the effectiveness of mHealth interventions varied widely by study, all reviews concluded that mHealth was a feasible option and had the potential for improving patient health when compared with standard care, especially for glycemic control $\left(-0.3 \%\right.$ to $-0.5 \%$ greater reduction in hemoglobin $\left.\mathrm{A}_{1 \mathrm{c}}\right)$ and weight reduction $(-1.0 \mathrm{~kg}$ to $-2.4 \mathrm{~kg}$ body weight). Overall, the existing 6 meta-analysis studies showed pooled favorable effects of these mHealth interventions $(-0.79,95 \% \mathrm{CI}-1.17$ to -0.42 ; I2 $=90.5)$.

Conclusions: mHealth interventions are promising, but there is limited evidence about their effectiveness in glycemic control and weight reduction. Future research to develop evidence-based mHealth strategies should use valid measures and rigorous study designs. To enhance the effectiveness of mHealth interventions, future studies are warranted for the optimal formats and 
the frequency of contacting patients, better tailoring of messages, and enhancing usability, which places a greater emphasis on maintaining effectiveness over time.

(JMIR Mhealth Uhealth 2020;8(4):e15400) doi: $10.2196 / 15400$

\section{KEYWORDS}

diabetes mellitus; obesity; overweight; mHealth; mobile app; telemedicine

\section{Introduction}

\section{Background}

Diabetes and obesity have become global epidemics [1,2]. The global prevalence of type 2 diabetes mellitus (T2DM) and overweight/obesity among adults had increased from $9 \%$ in 2014 [3] to 40\% in 2016 [4]. They both have significant and overlapping health and economic consequences, such as excess morbidity and mortality and health care resource utilization $[5,6]$. The global direct cost of diabetes and obesity has been estimated at US \$825 billion and US \$2 trillion per year, respectively $[7,8]$. However, patients often do not have adequate access to or cannot afford health care. Many others are not able to adhere to their treatment regimen, particularly in low-resource settings [9]. These diseases are difficult to manage effectively, and thus, patients suffer from more complications, in addition to the financial burden on themselves and society $[9,10]$. Thus, providing adequate health care services that enable patients to manage these chronic diseases is critical.

Self-management practices, such as maintaining a healthy diet and weight, engaging in adequate physical activity (PA), using prescribed medications consistently, frequently checking body weight and blood sugar levels, and maintaining good mental health habits, help patients control diabetes and obesity efficiently [11]. Previous studies have shown that self-management support in diabetes improves hemoglobin $\mathrm{A}_{1 \mathrm{c}}$ $\left(\mathrm{HbA}_{1 \mathrm{c}}\right)$ levels, reduces risks of developing life-threatening complications, and positively affects patient psychosocial and behavioral health [6]. However, the lack of individualized and coordinated care, inconvenient and costly education programs, and poor patient-provider communication make self-management practices challenging to adhere to and maintain. Effective services and methods for self-management are needed to reduce health care costs associated with these conditions, while improving the patient's quality of life [12].

Emerging mobile health (mHealth) approaches may help meet these needs. In both developed and developing countries, mobile technology and device usage has been rapidly increasing and plays a vital role in people's daily life [13]. Mobile technology provides mobility, instant access, and direct communication, which allows for faster transfer of health information and efficient health management assistance for patients [14,15]. It can also help provide better and expanded access to more affordable health services in low-income countries and low socioeconomic status groups in middle- and high-income countries [16]. Mobile technologies, specifically mobile apps, present an opportunity to help patients improve their adherence to health care providers' advice, enhance patient-provider communication, and help facilitate and maintain behavioral changes $[17,18]$. mHealth is increasingly being used to improve the access and delivery of health services, treatment adherence, and management of various diseases and health risk-altering behaviors, such as HIV/AIDS, malaria, tuberculosis, diabetes, asthma, obesity, and smoking [16]. However, research on the applications of mHealth is still at an early stage of development and translation, and many unanswered questions remain.

The availability of commercial chronic disease self-management apps has been increasing rapidly $[19,20]$. Commercial apps may offer patients many high-quality choices in the self-management of their diseases and conditions. However, the large number of these apps makes it difficult for patients and health care providers to choose among the options wisely. Furthermore, only a small proportion of apps, other mobile devices, and programs have been appropriately tested for effectiveness.

Some previous reviews, including ours, have described the development of app technologies and their utility for patients with obesity, diabetes, and other chronic conditions [19,21-37]. However, their scope did not adequately address the effectiveness of mHealth for diabetes and obesity treatment and management. Many reviews have concluded that mHealth is promising for disease control but reported inconsistent findings on its effectiveness. Furthermore, the methods used in previous reviews have often been flawed for reasons such as not providing quantitative results, conducting a quantitative analysis with clinical/nonclinical trials and other study designs together, not using standardized data extraction, and a limited scope of review [24,35]. A thorough review of the evidence is needed and can help guide future research and interventions [38,39].

\section{Objectives}

This study evaluated the effectiveness of mHealth interventions for diabetes and obesity treatment/management by examining published systematic reviews and meta-analyses and provided recommendations for future research and interventions.

\section{Methods}

\section{Study Selection}

\section{Database and Literature Search Strategy}

We searched the PubMed, IEEE Xplore Digital Library, and Cochrane databases to identify systematic reviews and meta-analyses published in English between January 1, 2005, and October 1, 2019, that evaluated the effectiveness of mHealth interventions for obesity and/or diabetes treatment/management. For the search, combinations of key terms were used in the PubMed, for example, "mhealth[Title/Abstract] AND (obesity[Title/Abstract] OR diabetes*[Title/Abstract]) AND review[Title/Abstract]." Search results were further screened 
manually by study title, abstract, and full text on the basis of inclusion and exclusion criteria.

The initial search yielded 95 articles. After eliminating duplicates and studies that did not fit the inclusion criteria, 17 reviews meeting the inclusion criteria remained; 6 of the 17 reviews were meta-analyses with randomized controlled trials (RCTs; Figure 1). The 17 reviews assessed 55,604 original intervention studies.

Figure 1. A flow chart of the literature search and study selection procedures. mHealth: mobile health.

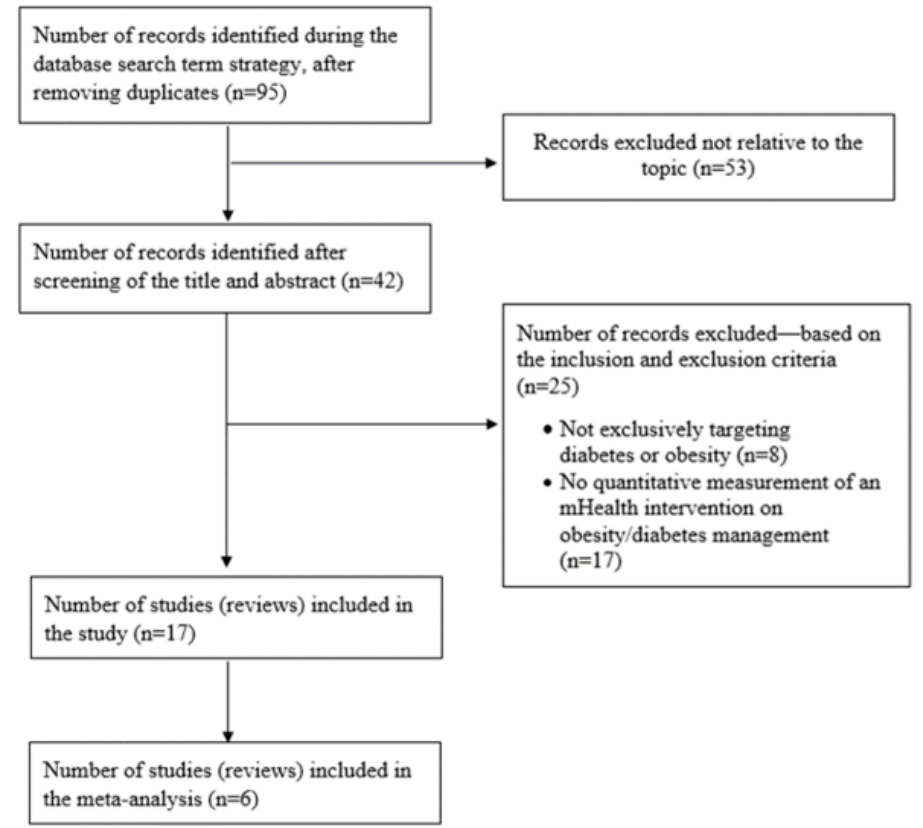

\section{Study Inclusion Criteria}

Studies were included if they (1) reviewed intervention studies on patients with obesity or/and diabetes; (2) were a systematic review and/or a meta-analysis; (3) tested an mHealth intervention (eg, use of mobile devices, apps, and text message) for managing or treating obesity/diabetes while measuring clinical biomarkers, treatment adherence, or health-related behaviors (eg, healthy eating and exercise); and (4) provided quantitative results examining the effectiveness of the intervention (or use of the mHealth devices/programs).

\section{Study Exclusion Criteria}

Studies were excluded if they (1) did not explicitly target diabetes or obesity; (2) were diabetes or obesity prevention studies, not using an mHealth-based intervention program; and (3) did not report quantitative outcomes of mHealth intervention effects in managing obesity or diabetes.

\section{Study Quality Assessment}

We used the Assessment of Multiple Systematic Reviews (AMSTAR 2) to assess the quality of selected studies by 16 criteria (eg, study selection, data extraction, assessing risk of bias, study description, and statistical methods) according to the study characteristics [40]. We assigned 1 point to each item that scored yes and summed these to calculate a total score (ranging from 0 to 16) for each review. We classified the quality of systematic reviews as high (score range 12-16), moderate (score range 9-11), low (score range 5-8), or critically low (score range 0-4; Multimedia Appendix 1) [41].

\section{Data Extraction and Statistical Analysis}

Data were reviewed and extracted by 2 coauthors following the Preferred Reporting Items for Systematic Review and Meta-Analysis guidelines [42]. The information extracted included study year; design; objective; literature search scope and date; the number of articles accessed and included in the systematic review; and nature of the intervention, such as application type and targeted function, outcome measures related to clinical biomarkers, treatment adherence and health-related behaviors, and effectiveness of the mHealth intervention.

Using mixed effect models, we conducted a meta-analysis to evaluate the overall effectiveness of mHealth interventions on the basis of other published meta-analysis results with RCTs. The STATA (StataCorp LLC) metan command was used to calculate pooled estimates of mean differences in changes in clinical outcomes such as $\mathrm{HbA}_{1 \mathrm{c}}$, body weight, and $\mathrm{BMI}$ between intervention and control groups [21-23,32-34].

\section{Results}

\section{Main Characteristics of the 17 Included Reviews}

\section{Study Topics and Study Design}

Multimedia Appendix 2 describes the characteristics of the 17 reviews: 7 studies were conducted in the United States and the others were conducted in Australia $(n=1)$, Canada $(n=1)$, China $(n=3)$, Germany $(n=1)$, New Zealand $(n=1)$, South Korea $(n=1)$, Spain $(\mathrm{n}=1)$, and the United Kingdom $(\mathrm{n}=1)$. Regarding study design, 15 of the reviews were based on clinical trials, of which 9 included only RCTs, whereas 6 also included quasi-experimental studies. One review was rated as critically low quality (AMSTAR 2 score 0-4), 5 were rated as low quality 
(AMSTAR 2 score 5-8), 5 were rated as moderate quality (AMSTAR 2 score 9-11), and 6 were categorized as high quality (AMSTAR 2 score 12-16). Of the 17 reviews, 10 reviewed mHealth interventions in patients with diabetes, 6 in patients with overweight/obesity, and 1 included both conditions. Meta-analyses for various health outcomes were conducted in 6 reviews with RCTs.

We conducted the meta-analysis of the mean difference on the basis of the results reported in the 6 reviews using a mixed effect model. The STATA metan command was used to calculate pooled estimates, with confidence limits of mean difference in clinical outcomes. The $\mathrm{I}^{2}$ statistic quantifies the percentage of variability that can be attributed to between-study differences.

The mean difference was calculated by subtracting the level of clinical outcomes at the end of follow-up from the baseline, comparing the intervention and control groups. This allowed for a comparison of clinical improvement because of the mHealth interventions vs the control group.

\section{Types of Mobile Health Interventions}

We categorized the mHealth interventions studied into 5 types (Multimedia Appendix 2): (1) an app, which uses smartphones to deliver educational materials or help patients self-manage their health condition; (2) web-based tools used to provide patient education and/or advice on self-management; (3) text messaging, which uses mobile phone text messages as the primary mode of communication between patients and health care providers; (4) a portable monitoring device/personal digital assistant (PDA), which typically offers patient data collection over a wireless connection and can monitor patients' physiological status; and (5) a pedometer that counts the number of steps taken in a day. These classifications were made on the basis of several considerations, including simplicity, understandability for a nontechnical audience, and the technological complexity involved in the intervention [31].

Mobile apps were the most widely studied intervention type (15 reviews), followed by text messaging (11 reviews) and PDAs (5 reviews). Regarding the major targeted functions of the mHealth interventions reviewed, self-monitoring and management was most common (15 reviews), followed by education or health promotion (8 reviews), reminders or alerts (5 reviews), feedback ( 3 reviews), social or peer support (2 reviews), and counseling or entertainment (1 review; see Multimedia Appendices 2 and 3).

\section{Targeted Outcomes}

All 17 reviews examined changes in clinical biomarkers as outcomes, whereas 9 evaluated health-related behaviors and 7 assessed treatment adherence (Multimedia Appendix 2). $\mathrm{HbA}_{1 \mathrm{c}}$ levels were included as clinical biomarkers in all the reviews of diabetes, whereas body weight/weight status (6 reviews) and BMI (5 reviews) were the main outcomes for obesity intervention reviews. Blood pressure (4 reviews), serum lipid/cholesterol levels (4 reviews), waist circumference, severe hypoglycemia/adverse effects ( 1 review), and C-reactive protein level (1 review) were also explored. For measuring treatment adherence, medication/treatment adherence and glycemic self-control/monitoring were most common. As indicators of health-related behaviors, PA and diet were frequently measured $(n=6)$, whereas PA alone $(n=1)$, other obesity-related behaviors, or self-care behaviors were less frequently reviewed $(n=2)$.

\section{The Effectiveness of Mobile Health Interventions in Managing Obesity or Diabetes}

\section{Clinical Outcomes}

We found much heterogeneity in the effectiveness of mHealth interventions for clinical biomarkers (Multimedia Appendix 3). For blood glucose control (including $\mathrm{HbA}_{1 \mathrm{c}}$ ), 8 reviews reported statistically significant or large improvements (more than or equal to half of the included studies) [21-23,25,26,29-31], although another 3 reported low improvements (less than half of the included articles) [24,27,28]. Treatment effects on BMI, weight, and waist circumference varied; 5 reviews found large improvements [31-35] and 3 reported small or no effect of the mHealth interventions [23,36,37]. mHealth interventions were found ineffective for improving serum lipids changes in 2 reviews [23,28], whereas 1 review found a few positive changes in cholesterol levels [29]. Blood pressure levels showed small improvements in 2 reviews [24,29], but 2 other reviews found no effect [23,28]. The heterogeneous results may reflect differences in study subjects (eg, T2DM vs type 1 diabetes mellitus [T1DM]) [21,30] and the severity of symptoms $\left(\mathrm{HbA}_{1 \mathrm{c}}<8 \%\right.$ vs $\left.\mathrm{HbA}_{1 \mathrm{c}} \geq 8 \%\right)$ [23]. The small number of reviews on serum lipids, cholesterol, and blood pressure (eg, $<5$ reviews) may be insufficient to examine the effectiveness of mHealth for these parameters.

Regarding the meta-analyses, 3 reviews reported on the effect of mobile apps on $\mathrm{HbA}_{1 \mathrm{c}}$ levels in diabetes [21-23]. A meta-analysis indicated a significant reduction in $\mathrm{HbA}_{1 \mathrm{c}}$ from $0.25 \%$ (95\% CI -0.41 to -0.09 ) [21] to $0.48 \%$ (95\% CI -0.78 to -0.19 ) [22], presented in Table 1 and Figure 2, but with substantial heterogeneity in the pooled effect ( $\mathrm{I}^{2}$ up to $\left.77 \%\right)$. In particular, differences between the mHealth intervention group and the control group were significant for patients with $\mathrm{HbA}_{1 \mathrm{c}}$ $<8 \%$ at baseline by $-0.33 \%\left(-3.61 \mathrm{mmol} / \mathrm{mol} ; \mathrm{I}^{2}=70 \%\right)$, whereas it was not significant in the patients with $\mathrm{HbA}_{1 \mathrm{c}} \geq 8 \%$ $(P=.33)$ [23]. In addition, larger reductions were noticed after app use in $\mathrm{HbA}_{1 \mathrm{c}}$ among patients with T2DM $(-0.67 \%, 95 \%$ $\mathrm{CI}-1.03$ to -0.30 ) [22] compared with patients with T1DM $(-0.37 \%, 95 \% \mathrm{CI}-0.86$ to -0.12$)$.

A meta-analysis on RCTs consistently found that app use was associated with significant improvements in body weight and BMI [32-34] from $-1.04 \mathrm{~kg}\left(95 \% \mathrm{CI}-1.75\right.$ to $\left.-0.34 ; \mathrm{I}^{2}=41 \%\right)$ [33] to $-2.35 \mathrm{~kg}\left(95 \% \mathrm{CI}-2.84\right.$ to $\left.-1.87 ; \mathrm{I}^{2}=94 \%\right)$ [32] and from $-0.43 \mathrm{~kg} / \mathrm{m}^{2}$ (95\% CI -0.74 to $\left.-0.13 ; \mathrm{I}^{2}=50 \%\right)$ [33] to $-0.77 \mathrm{~kg} / \mathrm{m}^{2}$ (95\% CI -1.01 to $-0.52 ; \mathrm{I}^{2}=0 \%$ ) [32] than the control group, respectively. When stratified by the application type, only mobile-based interventions showed significant body weight loss $\left(-1.78 \mathrm{~kg}, 95 \% \mathrm{CI}-2.92\right.$ to $\left.-0.63 ; \mathrm{I}^{2}=16 \%\right)$, whereas PDA-based interventions showed nonsignificant changes $(-0.23$ $\mathrm{kg}, 95 \% \mathrm{CI}-0.87$ to $0.41 ; \mathrm{I}^{2}=0.0 \%$ ) [34]. 
Table 1. Summary of clinical outcomes and behavioral changes from 18 meta-analyses reported in 6 reviews of diabetes and obesity mobile health interventions.

\begin{tabular}{|c|c|c|c|c|c|}
\hline Outcomes & References $^{\mathrm{a}}$ & $\begin{array}{l}\text { Tested interventions/tar- } \\
\text { get patient }\end{array}$ & $\begin{array}{l}\text { Intervention vs } \\
\text { control groups }\end{array}$ & $\begin{array}{l}\text { Estimated effect of intervention: meta- } \\
\text { analysis results of the mean difference } \\
\text { between intervention and control groups }\end{array}$ & Conclusions \\
\hline $\mathrm{HbA}_{1 \mathrm{c}}{ }^{\mathrm{b}}$ & Wang et al [21] & $\begin{array}{l}\text { Self-management of pa- } \\
\text { tients with } \mathrm{T}^{\mathrm{D}} \mathrm{DM}^{\mathrm{c}}\end{array}$ & $\begin{array}{l}\text { Mobile app or text } \\
\text { messaging interven- } \\
\text { tion vs standard } \\
\text { care }\end{array}$ & $\begin{array}{l}-0.25 \%(95 \% \mathrm{CI}-0.41 \text { to }-0.09 ; \\
\left.\mathrm{I}^{2}=12 \%\right) \\
\text { Subgroup analysis-age: teenagers } \\
-0.05 \% \text { ( } 95 \% \mathrm{CI}-0.43 \text { to } 0.33 ; \\
\left.\mathrm{I}^{2}=0 \%\right) \text {; adults }-0.29 \% \text { (95\% CI } \\
\left.-0.47 \text { to }-0.11 ; \mathrm{I}^{2}=48 \%\right) \\
\text { - Subgroup analysis-intervention: } \\
\text { text message }-0.20 \%(95 \% \mathrm{CI}-0.73 \\
\left.\text { to } 0.32 ; \mathrm{I}^{2}=0 \%\right) ; \text { mobile apps }-0.25 \% \\
\left(95 \% \mathrm{CI}-0.42 \text { to }-0.08 ; \mathrm{I}^{2}=49 \%\right) \\
\text { Subgroup analysis-duration: } \geq 6 \\
\text { months }-0.29 \%(95 \% \mathrm{CI}-0.46 \text { to } \\
\left.-0.11 ; \mathrm{I}^{2}=32 \%\right) ;<6 \text { months }-0.01 \% \\
\left(95 \% \mathrm{CI}-0.44 \text { to } 0.41 ; \mathrm{I}^{2}=0 \%\right)\end{array}$ & $\begin{array}{l}\text { mHealth } \\
\text { vors }\end{array}$ \\
\hline $\mathrm{HbA}_{1 \mathrm{c}}$ & Wu et al [22] & $\begin{array}{l}\text { Self-management of pa- } \\
\text { tients with diabetes }\end{array}$ & $\begin{array}{l}\text { Mobile app inter- } \\
\text { vention vs standard } \\
\text { care alone }\end{array}$ & $\begin{array}{l}-0.48 \% \text { (95\% CI }-0.78 \text { to }-0.19 ; \\
\mathrm{I}^{2}=76 \% \text { ) } \\
\text { Subgroup analysis: patients with } \\
\text { T2DM } \mathrm{D}^{\mathrm{e}}-0.67 \% \text { (95\% CI }-1.03 \text { to } \\
\left.-0.30 ; \mathrm{I}^{2}=47 \%\right) \text {; patients with } \mathrm{T} 1 \mathrm{DM} \\
-0.37 \% \text { (95\% CI }-0.86 \text { to }-0.12 ; \\
\left.\mathrm{I}^{2}=86 \%\right)\end{array}$ & mHealth favors \\
\hline $\mathrm{HbA}_{1 \mathrm{c}}$ & Cui et al [23] & $\begin{array}{l}\text { Self-management of pa- } \\
\text { tients with T2DM }\end{array}$ & $\begin{array}{l}\text { Smartphone app } \\
\text { strategies vs stan- } \\
\text { dard diabetes care }\end{array}$ & $\begin{array}{l}-0.40 \%(95 \% \mathrm{CI}-0.69 \text { to }-0.11 ; \\
\left.\mathrm{I}^{2}=77 \%\right) \\
\text { Subgroup analysis: baseline } \\
\mathrm{HbA}_{1 \mathrm{c}}<8 \%-0.33 \%(95 \% \mathrm{CI}-0.59 \\
\left.\text { to }-0.06 ; \mathrm{I}^{2}=70 \%\right)\end{array}$ & mHealth favors \\
\hline Body weight & Park et al [32] & $\begin{array}{l}\text { Weight loss interventions } \\
\text { on patients with } \mathrm{OWB}^{\mathrm{f}}\end{array}$ & $\begin{array}{l}\text { Mobile app/text } \\
\text { messaging interven- } \\
\text { tion vs nonmobile } \\
\text { device care (stan- } \\
\text { dard) }\end{array}$ & $\begin{array}{l}-2.35 \mathrm{~kg}(95 \% \mathrm{CI}-2.84 \text { to }-1.87 ; \\
\left.\mathrm{I}^{2}=94 \%\right) \\
\text { Subgroup analysis-duration: at } 6 \\
\text { months }-2.66 \mathrm{~kg}(95 \% \mathrm{CI}-3.94 \text { to } \\
\left.-1.38 ; \mathrm{I}^{2}=95 \%\right) ; \text { at } \geq 12 \text { months }-1.23 \\
\mathrm{~kg}\left(95 \% \mathrm{CI}-2.25 \text { to }-0.21 ; \mathrm{I}^{2}=0 \%\right)\end{array}$ & mHealth favors \\
\hline Body weight & Mateo et al [33] & $\begin{array}{l}\text { Weight loss and } \mathrm{PA}^{\mathrm{g}} \\
\text { promotion on patients } \\
\text { with OWB }\end{array}$ & $\begin{array}{l}\text { Mobile app inter- } \\
\text { vention vs the con- } \\
\text { trol diet }\end{array}$ & $\begin{array}{l}-1.04 \mathrm{~kg}(95 \% \mathrm{CI}-1.75 \text { to }-0.34 \\
\left.\mathrm{I}^{2}=41 \%\right)\end{array}$ & mHealth favors \\
\hline Body weight & Khokhar et al [34] & $\begin{array}{l}\text { Weight loss interventions } \\
\text { on patients with OWB }\end{array}$ & $\begin{array}{l}\text { Mobile electronic } \\
\text { device intervention } \\
\text { vs the control }\end{array}$ & $\begin{array}{l}-1.09 \mathrm{~kg}(95 \% \mathrm{CI}-2.12 \text { to }-0.05 ; \\
\left.\mathrm{I}^{2}=50 \%\right) \\
\text { Subgroup analysis-duration: } \leq 6 \\
\text { months }-0.97 \mathrm{~kg}(95 \% \mathrm{CI}-2.23 \text { to } \\
\left.0.30 ; \mathrm{I}^{2}=47 \%\right) ;>6 \text { months }-1.20 \mathrm{~kg} \\
\left(95 \% \mathrm{CI}-3.34 \text { to } 0.94 ; \mathrm{I}^{2}=62 \%\right) \\
\text { Subgroup analysis-intervention: } \\
\text { mobile phone }-1.78 \mathrm{~kg}(95 \% \mathrm{CI} \\
\left.-2.92 \text { to }-0.63 ; \mathrm{I}^{2}=16 \%\right) ; \text { personal } \\
\text { digital assistant }-0.23 \mathrm{~kg}(95 \% \mathrm{CI} \\
\left.-0.87 \text { to } 0.41 ; \mathrm{I}^{2}=0.0 \%\right)\end{array}$ & mHealth favors \\
\hline
\end{tabular}




\begin{tabular}{|c|c|c|c|c|c|}
\hline Outcomes & References $^{\mathrm{a}}$ & $\begin{array}{l}\text { Tested interventions/tar- } \\
\text { get patient }\end{array}$ & $\begin{array}{l}\text { Intervention vs } \\
\text { control groups }\end{array}$ & $\begin{array}{l}\text { Estimated effect of intervention: meta- } \\
\text { analysis results of the mean difference } \\
\text { between intervention and control groups }\end{array}$ & Conclusions \\
\hline BMI & Park et al [32] & $\begin{array}{l}\text { Weight loss interventions } \\
\text { on patients with OWB }\end{array}$ & $\begin{array}{l}\text { Mobile app/text } \\
\text { messaging interven- } \\
\text { tion vs nonmobile } \\
\text { device care (stan- } \\
\text { dard) }\end{array}$ & $\begin{array}{l}-0.77 \mathrm{~kg} / \mathrm{m}^{2}(95 \% \mathrm{CI}-1.01 \text { to }-0.52 ; \\
\left.\mathrm{I}^{2}=0 \%\right) \\
\text { Subgroup analysis-duration: at } 3 \\
\text { months }-1.10 \mathrm{~kg} / \mathrm{m}^{2} \text { (95\% CI }-2.79 \\
\left.\text { to } 0.59 ; \mathrm{I}^{2}=95 \%\right) ; \text { at } 6 \text { months }-0.67 \\
\mathrm{~kg} / \mathrm{m}^{2}(95 \% \mathrm{CI}-0.71 \text { to }-0.63 ; \\
\left.\mathrm{I}^{2}=0 \%\right)\end{array}$ & mHealth favors \\
\hline BMI & Mateo et al [33] & $\begin{array}{l}\text { Weight loss and PA pro- } \\
\text { motion on patients with } \\
\text { OWB }\end{array}$ & $\begin{array}{l}\text { Mobile app inter- } \\
\text { vention vs the con- } \\
\text { trol diet }\end{array}$ & $\begin{array}{l}-0.43 \mathrm{~kg} / \mathrm{m}^{2}(95 \% \text { CI }-0.74 \text { to }-0.13 \\
\left.\mathrm{I}^{2}=50 \%\right)\end{array}$ & mHealth favors \\
\hline Physical activity & Mateo et al [33] & $\begin{array}{l}\text { Weight loss and PA pro- } \\
\text { motion on patients with } \\
\text { OWB }\end{array}$ & $\begin{array}{l}\text { Mobile app inter- } \\
\text { vention vs control } \\
\text { intervention }\end{array}$ & $\begin{array}{l}\text { - Standardized mean difference in net } \\
\text { change } 0.40 \text { (95\% CI -0.07 to 0.87; } \\
\left.\mathrm{I}^{2}=93 \%\right)\end{array}$ & $\begin{array}{l}\text { No significant } \\
\text { difference }\end{array}$ \\
\hline
\end{tabular}

\footnotetext{
${ }^{\mathrm{a}}$ We selected 6 meta-analyses on randomized controlled trial studies. Please see our pooled meta-analysis presented in Figure 2.

${ }^{\mathrm{b}} \mathrm{HbA}_{1 \mathrm{c}}$ : hemoglobin $\mathrm{A}_{1 \mathrm{c}}$ (glycated hemoglobin).

${ }^{\mathrm{c}}$ T1DM: type 1 diabetes mellitus.

${ }^{\mathrm{d}}$ mHealth: mobile health.

T2DM: type 2 diabetes mellitus.

fOWB: overweight and obesity.

${ }^{\mathrm{g}} \mathrm{PA}$ : physical activity.
}

Figure 2. A meta-analysis of mean differences in changes in clinical outcomes after an intervention, mobile health versus control groups. $\mathrm{HbA}_{1 \mathrm{c}}$ : hemoglobin $\mathrm{A}_{1 \mathrm{c}}$.

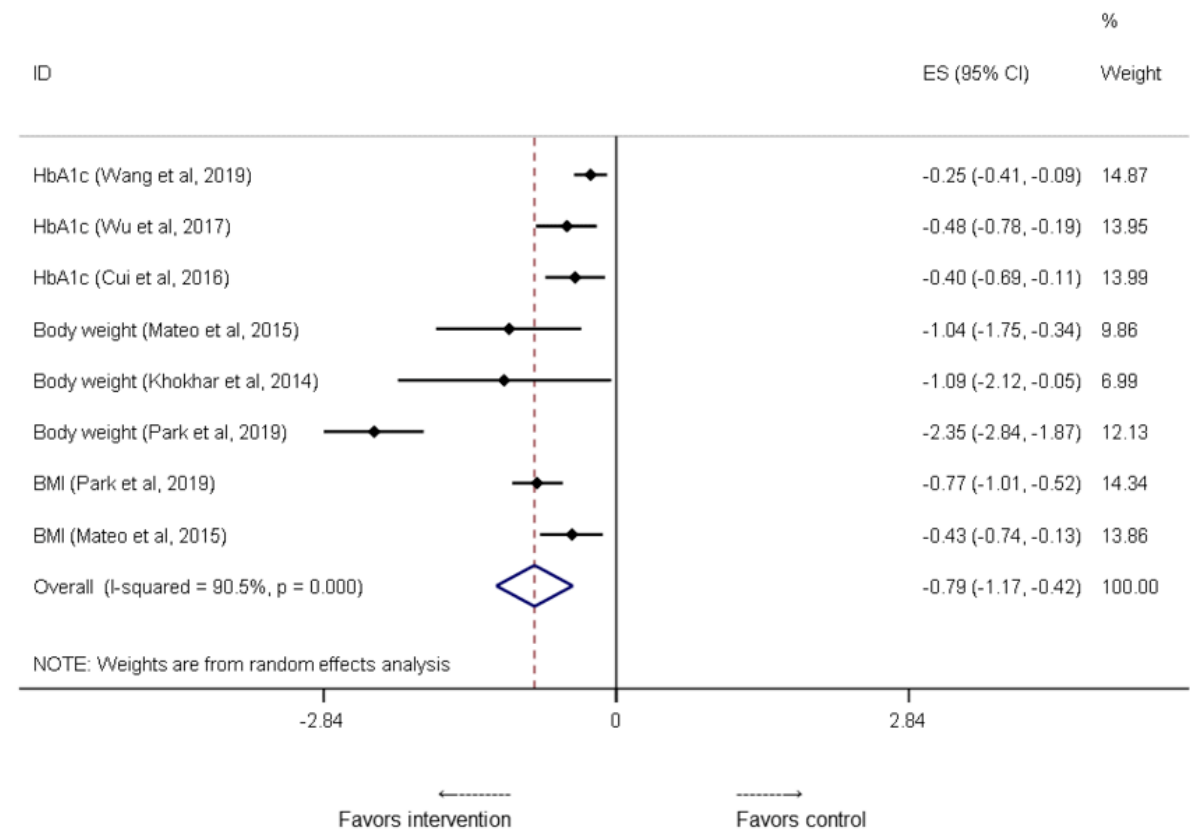

\section{Treatment Adherence}

Relatively few reviews examined the treatment effect of mHealth interventions and reported inconsistent results. Out of the 7 reviews that investigated mHealth intervention effects on treatment adherence, 4 reviews found a moderate improvement in glycemic control $[23,26]$, greater adherence in the mHealth intervention group compared with the control group [35], or a reduced attrition rate during an obesity intervention program
[37]. However, the other 2 reviews found that fewer than half of the studies improved diabetes management practices $[24,28]$ or medication adherence [28].

\section{Behavioral Changes}

Results for behavioral changes were not consistent, and 3 diabetes reviews [24,26,28] and 1 obesity review [35] found a slight improvement in patients' diets, eating habits, and PA behaviors. However, 3 reviews found inconsistent behavioral 
changes by disease (diabetes vs obesity) [21] or type of behavior (eating habits/dietary intake vs PA) [36,37], and 1 review found no significant effect of mHealth interventions on the level of PA [33]. A meta-analysis of RCTs found a nonsignificant difference in PA between the intervention and control groups, with a standardized mean difference of 0.40 (95\% CI -0.07 to $0.87 ; \mathrm{I}^{2}=93 \%$; Table 1 ).

Our meta-analysis (see Figure 2) on results from the existing 6 meta-analysis studies on $\mathrm{HbA}_{1 \mathrm{c}}$, body weight, and BMI shows an overall effect of -0.79 (95\% CI -1.17 to -0.42 ; $\left.\mathrm{I}^{2}=90.5\right)$, which shows a pooled favorable effect of these mHealth interventions.

\section{Discussion}

\section{Principal Findings}

Although there is a strong interest among researchers, health care workers, and patients in mHealth interventions for the treatment of diabetes and obesity, overall, very little is known about its effectiveness. Moreover, at present, the use of mHealth interventions for these conditions is limited. To our knowledge, this is the first study that provides a comprehensive summary of research assessing the effectiveness of mHealth interventions for these conditions.

Published research has yielded mixed results. Examining evidence reported in 17 reviews that assessed a total of 55,604 original studies, this systematic review found that, overall, the impact of mHealth interventions on diabetes and obesity management is promising, especially in the areas of glycemic control and weight management. The majority of the 17 reviews focused on the self-monitoring functions of mHealth. Text messaging and apps were the primary types of mHealth interventions utilized to date. There was heterogeneity in the effectiveness of mHealth as diverse health outcomes (eg, blood pressure, weight, lipids, $\mathrm{HbA}_{1 \mathrm{c}}$, clinical biomarkers, treatment adherence, and health-related behavior changes) were tested in the original studies, but only a few studies with various study designs and populations (eg, clinical trials, nonclinical trials, and diverse patient subgroups by severity and disease type) and study focus (eg, incentive-driven technology) were available in the review. Nevertheless, all the 17 reviews concluded that mHealth was feasible and potentially can improve health outcomes among patients suffering from diabetes and/or obesity.

\section{Sources of Variations in Existing Research}

Clinical biomarkers such as glycemic control and weight change were the primary focus in evaluating the effect of mHealth interventions in the reviews assessed. For example, the change in $\mathrm{HbA}_{1 \mathrm{c}}$ pre- and postintervention was evaluated in 10 reviews. Of these, 7 reviews reported statistically significant/large improvements, but 3 reviews did not; 2 meta-analyses showed $0.25 \%$ to $0.48 \%$ greater changes in $\mathrm{HbA}_{1 \mathrm{c}}$ following an mHealth intervention compared with standard diabetes care. In contrast, only 4 reviews found some improvement in treatment adherence in all 7 reviews that assessed it. Furthermore, small or insignificant improvements in health-related behaviors were reported in 9 reviews.
Several factors could have caused substantial heterogeneity among the assessment of clinical biomarkers, treatment adherence, and health-related behaviors. First, a small number of original studies examining treatment adherence and behavioral changes might have underpowered the systematic approach in the literature review. Second, the inclusion criteria for the study design (eg, clinical/nonclinical trial and quasi-experimental study), study subjects (eg, mixture of patients with T1DM and T2DM, patients with T1DM only, or poorly controlled patients with diabetes), and application type were not controlled efficiently in the previous reviews. In addition, patient health-related behaviors may require more time to change than was generally allowed in the studies compared with the typically more rapid change in biomarkers, possibly because of the influence of cognitive biases, habits, and social behavioral norms [43].

\section{Implementation and Dissemination of Mobile Health Interventions}

In recent years, there has been explosive growth in the number of mobile apps [13,44], including mHealth apps. However, the large number of available mHealth apps may hinder the intended use of these apps [20,27,45]. Limited guidance and the commerce-influenced nature of internet-based searches make it difficult for patients to determine which apps could most effectively help manage their health conditions. The number of app functions has also been negatively correlated with user ratings [46]. Thus, a process of a truly objective app review has the potential to improve the ability of patients to find the appropriate apps that meet their needs and preferences [47]. In addition, this can also help health care providers in making clear recommendations of the best apps to use.

As education and health promotion can favorably influence clinical outcomes, app developers need to fully consider the needs of users in designing features for patients suffering from diabetes/obesity. For example, self-management should be promoted as a key feature in apps targeting patients with T1DM who may need to check their blood glucose level more frequently than those with T2DM. In addition, new mobile messaging services, such as Facebook Messenger, WhatsApp, Snapchat, and Instagram, now exceed the functionality of traditional text messaging. Relevantly, social media features are increasingly popular, particularly among young people. Social networks can help patients achieve behavioral changes by, for instance, providing peer support among patients with similar conditions [48]. Strategies targeting behavioral changes to enhance self-management for patients are not very common among existing apps [49-52]. Thus, mHealth apps could implement social media and network features to more effectively target young users and improve their care [53,54]. Of course, support and adoption of mHealth approaches for the treatment of diabetes and obesity by health care providers will be helpful in maximizing the potential future value of mHealth interventions.

\section{Limitations of Previous Reviews and the Original Mobile Health Intervention Studies}

The 17 reviews and the included intervention studies share some limitations. First, some reviews only included a small number 
of studies but examined a relatively large number of outcomes [23,27-29]. Second, most of the reviews examined studies conducted in developed countries; few reviews examined those from developing countries [21,28,31]. Third, a heterogeneous study design may cause substantial heterogeneity in meta-analyses or make it difficult to conduct a quantitative analysis across studies [23,28-31,33,37]. Fourth, the reviews included only a small number of RCTs [27,28,31,33,34], and many of the RCTs had short intervention periods [29,31,33,37]. Fifth, only a limited number of original studies reported changes in biomarkers, which may hinder the evaluation of mHealth interventions' clinical impact, especially on blood lipids and blood pressure $[23,24]$. Finally, the diverse features of the actual mHealth interventions further increase study heterogeneity [24].

\section{Limitations of This Study}

First, we examined the results reported in the 17 identified reviews without analyzing the findings from the original studies. Second, there was a high level of heterogeneity in the characteristics and findings of the 17 reviews. Thus, it was challenging to adequately interpret the effectiveness of mHealth interventions across reviews because of different study designs, objectives, and settings. Despite these limitations, this study provided a higher level of analysis and a comprehensive summary of the findings in the growing mHealth field. Compared with previous studies, our study has a number of unique contributions, including the following: (1) our study added quantitative evidence specifically on the applications of mHealth in diabetic and obesity care research and studied objective changes in biomarkers, treatment adherence, and health behaviors after an mHealth intervention, whereas previous studies were general and narratively described mHealth effects on diverse diseases using a small number of articles with low quality; (2) we conducted a meta-analysis on the intervention effects of clinical outcomes, which was lacking in the existing reviews; and (3) our review included newly published reviews that were not included in other studies. This helps identify best practices for fighting the epidemics of diabetes and obesity. In addition, we found a fairly consistent reduction in $\mathrm{HbA}_{1 \mathrm{c}}$ and body weight from mHealth interventions across multiple reviews.

\section{Recommendations for Future Research}

Regarding future evaluations of mHealth interventions, more rigorous study designs and strategies are needed to enable us to draw more precise and specific conclusions regarding their effectiveness for diabetes and obesity management. To enhance app design, including user ratings and experiences may be useful in developing evidence-based strategies. The level to which users truly engage with these mHealth apps is not yet clear. Patient-centered self-monitoring with personalized feedback is important in behavioral change and has been shown to improve user engagement and adherence [55]. Designing app functions relevant to the users on the basis of their age and sex, type of diabetes, and geographical location would improve the targeting and effectiveness of mHealth interventions.

To promote an evidence-based approach in mHealth use for diabetes and obesity management, multiple validation tests and, when appropriate, regulations will be needed. Objective and validated measures should be used, in particular, when studying behavioral changes following mHealth interventions. Furthermore, there is a need to identify and focus on high-risk groups (eg, low socioeconomic status populations), as most previous reviews did not include studies conducted in these populations.

In conclusion, findings from the 17 reviews, including 6 meta-analyses published since 2005 , suggested promising but limited evidence on the effectiveness of mHealth interventions for diabetes and obesity management. Self-management, monitoring, and use of text messaging and apps are the primary target functions and application types of mHealth investigated in the field. More rigorous study designs should be applied in future studies for assessing the impact of mHealth interventions on diabetes and obesity management. To enhance the effectiveness of mHealth interventions, studies are warranted for the optimal formats and the frequency of contacting patients, using theory-based interventions; for the better tailoring of messages to the specific needs and communication style of recipients; and for enhancing the usability by adapting approaches to recipients with varying degrees of technological and health literacy, thus placing a greater emphasis on maintaining effectiveness over time.

\section{Acknowledgments}

This work was supported by a research grant from the US National Institutes of Health, the Eunice Kennedy Shriver National Institute of Child Health and Human Development (U54HD070725), which YW received while he worked at the Johns Hopkins University and established a global center of excellence. The content of the paper is solely the responsibility of the authors and does not necessarily represent the official views of the funder.

\section{Conflicts of Interest}

None declared.

\section{Multimedia Appendix 1}

Methodological quality of 17 studies based on AMSTAR2 criteria.

[DOCX File, 16 KB-Multimedia Appendix 1] 


\section{Multimedia Appendix 2}

Characteristics of 17 review studies on the effectiveness of mobile health interventions for diabetes and obesity management. [DOCX File, 25 KB-Multimedia Appendix 2]

\section{Multimedia Appendix 3}

Summary of findings from the 17 reviews on the effectiveness of mobile health interventions for diabetes and obesity management. [DOCX File, $21 \mathrm{~KB}-$ Multimedia Appendix 3]

\section{References}

1. Lim H, Nguyen T, Choue R, Wang Y. Sociodemographic disparities in the composition of metabolic syndrome components among adults in South Korea. Diabetes Care 2012 Oct;35(10):2028-2035 [FREE Full text] [doi: 10.2337/dc11-1841] [Medline: 22837361]

2. Wang Y, Wang L, Qu W. New national data show alarming increase in obesity and noncommunicable chronic diseases in China. Eur J Clin Nutr 2017 Jan;71(1):149-150. [doi: 10.1038/ejen.2016.171] [Medline: 27703162]

3. World Health Organization. 2018 Oct 30. Diabetes URL: http://www.who.int/news-room/fact-sheets/detail/diabetes [accessed 2018-07-24]

4. World Health Organization. 2018 Feb 16. Obesity and Overweight URL: http://www.who.int/news-room/fact-sheets/detail/ obesity-and-overweight [accessed 2018-07-24]

5. World Health Organization. 2018. Global Health Estimates 2016: Deaths by Cause, Age, Sex, by Country and by Region, 2000-2016 URL: https://www.who.int/healthinfo/global burden disease/estimates/en/ [accessed 2018-07-24]

6. Powers MA, Bardsley J, Cypress M, Duker P, Funnell MM, Fischl AH, et al. Diabetes Self-management Education and Support in Type 2 Diabetes: A Joint Position Statement of the American Diabetes Association, the American Association of Diabetes Educators, and the Academy of Nutrition and Dietetics. Clin Diabetes 2016 Apr;34(2):70-80 [FREE Full text] [doi: 10.2337/diaclin.34.2.70] [Medline: 27092016]

7. NCD Risk Factor Collaboration (NCD-RisC). Worldwide trends in diabetes since 1980: a pooled analysis of 751 population-based studies with 4.4 million participants. Lancet 2016 Apr 9;387(10027):1513-1530 [FREE Full text] [doi: 10.1016/S0140-6736(16)00618-8] [Medline: 27061677]

8. McKinsey \& Company. 2014 Oct. Overcoming Obesity: An Initial Economic Analysis URL: https://www.mckinsey.com/ ح/media/McKinsey/Business [accessed 2018-07-24]

9. Chen L, Magliano DJ, Zimmet PZ. The worldwide epidemiology of type 2 diabetes mellitus--present and future perspectives. Nat Rev Endocrinol 2011 Nov 8;8(4):228-236. [doi: 10.1038/nrendo.2011.183] [Medline: 22064493]

10. Gortmaker SL, Swinburn BA, Levy D, Carter R, Mabry PL, Finegood DT, et al. Changing the future of obesity: science, policy, and action. Lancet 2011 Aug 27;378(9793):838-847 [FREE Full text] [doi: 10.1016/S0140-6736(11)60815-5] [Medline: 21872752]

11. Jones H, Edwards L, Vallis TM, Ruggiero L, Rossi SR, Rossi JS, Diabetes Stages of Change (DiSC) Study. Changes in diabetes self-care behaviors make a difference in glycemic control: the Diabetes Stages of Change (DiSC) study. Diabetes Care 2003 Mar;26(3):732-737. [doi: 10.2337/diacare.26.3.732] [Medline: 12610030]

12. Collier A, Ghosh S, Hair M, Waugh N. Impact of socioeconomic status and gender on glycaemic control, cardiovascular risk factors and diabetes complications in type 1 and 2 diabetes: a population based analysis from a Scottish region. Diabetes Metab 2015 Apr;41(2):145-151. [doi: 10.1016/j.diabet.2014.09.004] [Medline: 25454092]

13. Carter A, Liddle J, Hall W, Chenery H. Mobile phones in research and treatment: ethical guidelines and future directions. JMIR Mhealth Uhealth 2015 Oct 16;3(4):e95 [FREE Full text] [doi: 10.2196/mhealth.4538] [Medline: 26474545]

14. Whittaker R, McRobbie H, Bullen C, Rodgers A, Gu Y. Mobile phone-based interventions for smoking cessation. Cochrane Database Syst Rev 2016 Apr 10;4:CD006611 [FREE Full text] [doi: 10.1002/14651858.CD006611.pub4] [Medline: 27060875]

15. Klonoff DC. The current status of mHealth for diabetes: will it be the next big thing? J Diabetes Sci Technol 2013 May 1;7(3):749-758 [FREE Full text] [doi: 10.1177/193229681300700321] [Medline: 23759409]

16. Kay M, Santos J, Takane M. mHealth: New Horizons for Health Through Mobile Technologies. Geneva: World Health Organization; 2011:;64(7):66-;64(7):71.

17. Goyal S, Cafazzo JA. Mobile phone health apps for diabetes management: current evidence and future developments. Q J Med 2013 Dec;106(12):1067-1069 [FREE Full text] [doi: 10.1093/ajmed/hct203] [Medline: 24106313]

18. Rho MJ, Kim HS, Chung K, Choi IY. Factors influencing the acceptance of telemedicine for diabetes management. Cluster Comput 2015;18(1):321-331. [doi: 10.1007/s10586-014-0356-1]

19. Marcolino MS, Oliveira JA, D'Agostino M, Ribeiro AL, Alkmim MB, Novillo-Ortiz D. The impact of mHealth interventions: systematic review of systematic reviews. JMIR Mhealth Uhealth 2018 Jan 17;6(1):e23 [FREE Full text] [doi: 10.2196/mhealth.8873] [Medline: 29343463] 
20. Tamony P, Holt R, Barnard K. The role of mobile applications in improving alcohol health literacy in young adults with type 1 diabetes: Help or hindrance? J Diabetes Sci Technol 2015 Aug 6;9(6):1313-1320 [FREE Full text] [doi: 10.1177/1932296815588559] [Medline: 26251369]

21. Wang X, Shu W, Du J, Du M, Wang P, Xue M, et al. Mobile health in the management of type 1 diabetes: a systematic review and meta-analysis. BMC Endocr Disord 2019 Feb 13;19(1):21 [FREE Full text] [doi: 10.1186/s12902-019-0347-6] [Medline: 30760280]

22. Wu Y, Yao X, Vespasiani G, Nicolucci A, Dong Y, Kwong J, et al. Mobile app-based interventions to support diabetes self-management: a systematic review of randomized controlled trials to identify functions associated with glycemic efficacy. JMIR Mhealth Uhealth 2017 Mar 14;5(3):e35 [FREE Full text] [doi: 10.2196/mhealth.6522] [Medline: 28292740]

23. Cui M, Wu X, Mao J, Wang X, Nie M. T2DM self-management via smartphone applications: a systematic review and meta-analysis. PLoS One 2016;11(11):e0166718 [FREE Full text] [doi: 10.1371/journal.pone.0166718] [Medline: 27861583]

24. de Ridder M, Kim J, Jing Y, Khadra M, Nanan R. A systematic review on incentive-driven mobile health technology: as used in diabetes management. J Telemed Telecare 2017 Jan;23(1):26-35. [doi: 10.1177/1357633X15625539] [Medline: 26888421]

25. Kebede MM, Liedtke TP, Möllers T, Pischke CR. Characterizing active ingredients of eHealth interventions targeting persons with poorly controlled type 2 diabetes mellitus using the behavior change techniques taxonomy: scoping review. J Med Internet Res 2017 Oct 12;19(10):e348 [FREE Full text] [doi: 10.2196/jmir.7135] [Medline: 29025693]

26. Dobson R, Whittaker R, Pfaeffli Dale L, Maddison R. The effectiveness of text message-based self-management interventions for poorly-controlled diabetes: a systematic review. Digit Health 2017;3:2055207617740315 [FREE Full text] [doi: 10.1177/2055207617740315] [Medline: 29942620]

27. Hood M, Wilson R, Corsica J, Bradley L, Chirinos D, Vivo A. What do we know about mobile applications for diabetes self-management? A review of reviews. J Behav Med 2016 Dec;39(6):981-994. [doi: 10.1007/s10865-016-9765-3] [Medline: 27412774]

28. Cotter AP, Durant N, Agne AA, Cherrington AL. Internet interventions to support lifestyle modification for diabetes management: a systematic review of the evidence. J Diabetes Complications 2014;28(2):243-251 [FREE Full text] [doi: 10.1016/j.jdiacomp.2013.07.003] [Medline: 24332469]

29. Mallow JA, Theeke LA, Barnes ER, Whetsel T, Mallow BK. Using mHealth tools to improve rural diabetes care guided by the chronic care model. Online J Rural Nurs Health Care 2014;14(1):43-65 [FREE Full text] [doi:

10.14574/ojrnhc.v14i1.276] [Medline: 26029005]

30. Baron J, McBain H, Newman S. The impact of mobile monitoring technologies on glycosylated hemoglobin in diabetes: a systematic review. J Diabetes Sci Technol 2012 Sep 1;6(5):1185-1196 [FREE Full text] [doi: 10.1177/193229681200600524] [Medline: 23063046]

31. Wang Y, Xue H, Huang Y, Huang L, Zhang D. A systematic review of application and effectiveness of mHealth interventions for obesity and diabetes treatment and self-management. Adv Nutr 2017 May;8(3):449-462 [FREE Full text] [doi: 10.3945/an.116.014100] [Medline: 28507010]

32. Park SH, Hwang J, Choi YK. Effect of mobile health on obese adults: a systematic review and meta-analysis. Healthc Inform Res 2019 Jan;25(1):12-26 [FREE Full text] [doi: 10.4258/hir.2019.25.1.12] [Medline: 30788177]

33. Mateo GF, Granado-Font E, Ferré-Grau C, Montaña-Carreras X. Mobile phone apps to promote weight loss and increase physical activity: a systematic review and meta-analysis. J Med Internet Res 2015 Nov 10;17(11):e253 [FREE Full text] [doi: 10.2196/jmir.4836] [Medline: 26554314]

34. Khokhar B, Jones J, Ronksley PE, Armstrong MJ, Caird J, Rabi D. Effectiveness of mobile electronic devices in weight loss among overweight and obese populations: a systematic review and meta-analysis. BMC Obes 2014;1:22 [FREE Full text] [doi: 10.1186/s40608-014-0022-4] [Medline: 26217509]

35. Bhardwaj NN, Wodajo B, Gochipathala K, Paul DP, Coustasse A. Can mHealth revolutionize the way we manage adult obesity? Perspect Health Inf Manag 2017;14(Spring):1a [FREE Full text] [Medline: 28566984]

36. Darling KE, Sato AF. Systematic review and meta-analysis examining the effectiveness of mobile health technologies in using self-monitoring for pediatric weight management. Child Obes 2017 Oct;13(5):347-355. [doi: 10.1089/chi.2017.0038] [Medline: 28471699]

37. Turner T, Spruijt-Metz D, Wen CK, Hingle MD. Prevention and treatment of pediatric obesity using mobile and wireless technologies: a systematic review. Pediatr Obes 2015 Dec;10(6):403-409 [FREE Full text] [doi: 10.1111/ijpo.12002] [Medline: 25641770]

38. Kitsiou S, Paré G, Jaana M. Effects of home telemonitoring interventions on patients with chronic heart failure: an overview of systematic reviews. J Med Internet Res 2015 Mar 12;17(3):e63 [FREE Full text] [doi: 10.2196/jmir.4174] [Medline: 25768664]

39. Paré G, Trudel MC, Jaana M, Kitsiou S. Synthesizing information systems knowledge: a typology of literature reviews. Inf Manag 2015;52(2):183-199. [doi: 10.1016/j.im.2014.08.008]

40. Shea BJ, Reeves BC, Wells G, Thuku M, Hamel C, Moran J, et al. AMSTAR 2: a critical appraisal tool for systematic reviews that include randomised or non-randomised studies of healthcare interventions, or both. Br Med J 2017 Sep 21;358:j4008 [FREE Full text] [doi: 10.1136/bmj.j4008] [Medline: 28935701] 
41. Wilhelmsen NC, Eriksson T. Medication adherence interventions and outcomes: an overview of systematic reviews. Eur J Hosp Pharm 2019 Jul;26(4):187-192. [doi: 10.1136/ejhpharm-2018-001725] [Medline: 31338165]

42. Moher D, Liberati A, Tetzlaff J, Altman DG, PRISMA Group. Preferred reporting items for systematic reviews and meta-analyses: the PRISMA statement. Int J Surg 2010;8(5):336-341 [FREE Full text] [doi: 10.1016/j.ijsu.2010.02.007] [Medline: 20171303]

43. Tronieri J, Wadden T, Diplomate AB, Alamuddin MB. NCBI - NIH. South Dartmouth (MA): MDText.com, Inc; 2000. Endotext: Behavioral Approaches to Obesity Management URL: https://www.ncbi.nlm.nih.gov/books/NBK278952/ [accessed 2019-07-24]

44. International Telecommunication Union (ITU). 2016. The World in 2016: ICT Facts and Figures URL: https://www.itu.int/ en/ITU-D/Statistics/Documents/facts/ICTFactsFigures2016.pdf [accessed 2019-07-24]

45. Bailey CJ, Kodack M. Patient adherence to medication requirements for therapy of type 2 diabetes. Int J Clin Pract 2011 Mar;65(3):314-322. [doi: 10.1111/j.1742-1241.2010.02544.x] [Medline: 21314869]

46. Arnhold M, Quade M, Kirch W. Mobile applications for diabetics: a systematic review and expert-based usability evaluation considering the special requirements of diabetes patients age 50 years or older. J Med Internet Res 2014 Apr 9;16(4):e104 [FREE Full text] [doi: 10.2196/jmir.2968] [Medline: 24718852]

47. Eng DS, Lee JM. The promise and peril of mobile health applications for diabetes and endocrinology. Pediatr Diabetes 2013 Jun;14(4):231-238 [FREE Full text] [doi: 10.1111/pedi.12034] [Medline: 23627878]

48. Laranjo L, Arguel A, Neves A, Gallagher A, Kaplan R, Mortimer N, et al. The influence of social networking sites on health behavior change: a systematic review and meta-analysis. J Am Med Inform Assoc 2015 Jan;22(1):243-256 [FREE Full text] [doi: 10.1136/amiajnl-2014-002841] [Medline: 25005606]

49. Azar KM, Lesser LI, Laing BY, Stephens J, Aurora MS, Burke LE, et al. Mobile applications for weight management: theory-based content analysis. Am J Prev Med 2013 Nov;45(5):583-589. [doi: 10.1016/j.amepre.2013.07.005] [Medline: 24139771]

50. Chen J, Cade JE, Allman-Farinelli M. The most popular smartphone apps for weight loss: a quality assessment. JMIR Mhealth Uhealth 2015 Dec 16;3(4):e104 [FREE Full text] [doi: 10.2196/mhealth.4334] [Medline: 26678569]

51. Morrissey EC, Corbett TK, Walsh JC, Molloy GJ. Behavior change techniques in apps for medication adherence: a content analysis. Am J Prev Med 2016 May;50(5):e143-e146. [doi: 10.1016/j.amepre.2015.09.034] [Medline: 26597504]

52. Payne H, Moxley V, MacDonald E. Health behavior theory in physical activity game apps: a content analysis. JMIR Serious Games 2015 Jul 13;3(2):e4 [FREE Full text] [doi: 10.2196/games.4187] [Medline: 26168926]

53. Giménez-Pérez G, Recasens A, Simó O, Aguas T, Suárez A, Vila M, et al. Use of communication technologies by people with type 1 diabetes in the social networking era. A chance for improvement. Prim Care Diabetes 2016 Apr;10(2):121-128. [doi: 10.1016/j.pcd.2015.09.002] [Medline: 26428527]

54. Vaala SE, Hood KK, Laffel L, Kumah-Crystal YA, Lybarger CK, Mulvaney SA. Use of commonly available technologies for diabetes information and self-management among adolescents with type 1 diabetes and their parents: a web-based survey study. Interact J Med Res 2015 Dec 29;4(4):e24 [FREE Full text] [doi: 10.2196/ijmr.4504] [Medline: 26715191]

55. Winter SJ, Sheats JL, King AC. The use of behavior change techniques and theory in technologies for cardiovascular disease prevention and treatment in adults: a comprehensive review. Prog Cardiovasc Dis 2016;58(6):605-612 [FREE Full text] [doi: 10.1016/j.pcad.2016.02.005] [Medline: 26902519]

\footnotetext{
Abbreviations

$\mathbf{H b A}_{1 \mathbf{c}}$ : hemoglobin $\mathrm{A}_{1 \mathrm{c}}$

mHealth: mobile health

PA: physical activity

PDA: personal digital assistant

RCT: randomized controlled trial

T1DM: type 1 diabetes mellitus

T2DM: type 2 diabetes mellitus
} 
Edited by G Eysenbach; submitted 08.07.19; peer-reviewed by A Mehdizadeh, $R$ Sun; comments to author 09.09.19; revised version received 04.11.19; accepted 26.01.20; published 28.04.20

Please cite as:

Wang Y, Min J, Khuri J, Xue H, Xie B, A Kaminsky L, J Cheskin L

Effectiveness of Mobile Health Interventions on Diabetes and Obesity Treatment and Management: Systematic Review of Systematic Reviews

JMIR Mhealth Uhealth 2020;8(4):e15400

URL: http://mhealth.jmir.org/2020/4/e15400/

doi: $10.2196 / 15400$

PMID: $\underline{32343253}$

(C) Youfa Wang, Jungwon Min, Jacob Khuri, Hong Xue, Bo Xie, Leonard A Kaminsky, Lawrence J Cheskin. Originally published in JMIR mHealth and uHealth (http://mhealth.jmir.org), 28.04.2020. This is an open-access article distributed under the terms of the Creative Commons Attribution License (https://creativecommons.org/licenses/by/4.0/), which permits unrestricted use, distribution, and reproduction in any medium, provided the original work, first published in JMIR mHealth and uHealth, is properly cited. The complete bibliographic information, a link to the original publication on http://mhealth.jmir.org/, as well as this copyright and license information must be included. 